\title{
Assessment of Knowledge and Attitude of Pharmacy Students on Safe and Quality Use of Vaccination: A Cross Sectional Study
}

\author{
Jibin Xavier, Jobin George, Rijinas EK, Jaseem EK, Muhammed Shahir \\ NA and Juny Sebastian* \\ Department of Pharmacy Practice, JSS College of Pharmacy, JSS Academy of Higher \\ Education and Research, Mysuru, Karnataka, India \\ *Corresponding Author: Juny Sebastian, Department of Pharmacy Practice, JSS \\ College of Pharmacy, JSS Academy of Higher Education and Research, Mysuru, \\ Karnataka, India. E-mail: junysebastian@jssuni.edu.in
}

Received: February 16, 2021

Published: March 16, 2021

(C) All rights are reserved by Juny Sebastian., et al.

\begin{abstract}
Introduction: Immunization is the ability of the human body to tolerate the presence of indigenous materials to the body and to eliminate the foreign particles from the body. To get a good immunity after vaccination, we need to take precautions on safe and quality use of vaccines.

Objective: To assess the knowledge and attitude of pharmacy students on safe and quality use of vaccines.

Methodology: This was a cross-sectional study conducted for a period of 6 months at JSS College of Pharmacy, Mysuru. Data was collected using a validated questionnaire. Collected data was assessed using unpaired T test ANOV A.

Result: Out of 502 students enrolled for the study, 84.46\% of them had adequate knowledge on safe and quality use of vaccines. The mean knowledge score of the study population was $12.29 \pm 3.95$. There was a statistically significant difference in the knowledge score of study population belong to categories such as Indian and other nationals ( $\mathrm{p} \mathrm{0.03)}$, urban and rural place of origin ( $\mathrm{p}$ 0.001) and students of different courses ( $\mathrm{p}$ 0.001).The lowest mean attitude score was observed among the category of study population belonged to nationalities other than India (1.42 \pm 0.54$)$.

Conclusion: Study suggest the need of educating the students on safe and quality use of vaccines, preferably topic can be added in the curriculum so that more attention will be given to this important topic.
\end{abstract}

Keywords: Safe and Quality Use of Vaccines; Knowledge and Attitude; Cross Sectional Study; Pharmacy Students

\section{Introduction}

The World Health Organization (WHO) states that vaccine helps the body's immune system to identify and fight against pathogens like viruses or bacteria that can cause diseases. Vaccination is one of the most effective ways to impede diseases [1,2]. Many children die all over the world mainly in developing countries due to hemophilia influenza, whooping cough (pertussis), hepatitis b and polio.
Children should be immunized in certain age to ensure their ability to fight against infection $[3,4]$. Immunization is the process of making a person resistant to infectious disease, by administration of vaccine. Vaccines stimulate own immune system, which protects subsequent infection on disease [3]. Immunization against infectious disease has probably saved more lives than any other public health intervention apart from the provision of clean water [2]. Currently immunization prevents 2-3 million deaths every year [4]. 
The most common reason stated in studies for requesting exemptions for vaccination was concerns of parents that the vaccines might cause some harm to their children. Parents exempted tehir children for vaccinated were more likely to report confidence in alternative medicine professionals and less likely to report confidence public health and government resources providing vaccination related information [5].

In some of the cases, adverse events and misconceptions about vaccines leads parents to reject the vaccination programme [6]. Studies have also shown that parents and other individuals cite health care professionals has the vital factor influencing to vaccinate their children themselves [7]. Hence, the role of health care providers is very important in determining the decision making of parents regarding vaccination [6]. According to a study conducted by Philip., et al. '5.7\% of parents thought that vaccines were not safe, and $21.5 \%$ said that their decision to vaccinate their children was not influenced by a health care. Pharmacists are the most accessible, trusted and recognized health care professionals in community practice, can promote vaccination programs easily to the community [8]. However $\mathrm{t}$ provide a remarkable practice, pharmacists needs to be knowledgeable up-to-date and needs to understand the potential problems in quality and safe use of vaccination. ${ }^{6,9}$ Hence this study is planned with the objective to assess pharmacy students knowledge and attitude on quality and safe use of vaccination.

\section{Methodology}

- Study Site: The study was conducted at JSS College of Pharmacy Mysuru which is a constituent college of JSS Academy of Higher Education and Research, Mysuru

- Study design: Cross sectional study

- Study period: Six months (November 2019 to April 2020)

- Study Population: Students of JSS College of Pharmacy, Mysuru.

Study criteria

Inclusion criteria

- Students studying various pharmacy related courses at JSS$\mathrm{CP}, \mathrm{Mysuru.}$

\section{Exclusion criteria}

- Students who are not willing to participate in the study
- Students studying at the college as a part of student exchange program or for any internships.

\section{Ethical clearance}

Ethical clearance of the study was obtained from localised institutional human ethical committee.

\section{Sources of data}

Data required for the study was collected by a validated questionnaire. The questionnaire consist of two sections: (1) General Information on the study population which had provisions to details of the study participants course, age, gender, family income, nationality, place of origin, occupation and education of father and mother. (2) Questionnaire on knowledge and attitude of pharmacy students on safe and quality use of vaccination. The questionnaire had 20 questions and each of the questions had three answer options such as yes, no and do not know.

\section{Study procedure}

Students of the college was approached and explained about the purpose of the study and the importance of filling the questionnaire. Eligible study participants were enrolled after taking the informed consent. The study participants were given sufficient time to fill the form. The completed questionnaire was collected for further analysis. Awarding one pint for the right option and zero for the wrong answers scored responses to each item. Median split method was used to categories the study population into adequate attitude and inadequate attitude. Collected data was entered into Microsoft Excel spreadsheet for easy calculation and retrieval followed by the assessment with the help of SPSS software version 22 .

\section{Results}

A total of 502 students participated in the cross sectional study. Among the study population $54.38 \%$ were females, $54.38 \%$ were students of B.Pharm and majority (97.22\%) were Indian nationals. Demographic details of the study population is presented in table 1.

Among the study population, $93.42 \%$ answered that vaccination prevent disease, but only $76.89 \%$ agreed that vaccination is the most cost effective public health intervention. Vaccination is for all ages was not known by $9.56 \%$ of the study population and $25.69 \%$ answered that vaccination is not for all ages. About $9.76 \%$ were not aware of the key role of vaccination in enhancing the immunization 


\begin{tabular}{|c|c|c|c|c|}
\hline \multicolumn{3}{|c|}{ Characteristics } & Number & Percentage \\
\hline Gender & \multicolumn{2}{|c|}{ Male } & 229 & $45.61 \%$ \\
\hline & \multicolumn{2}{|c|}{ Female } & 273 & $54.38 \%$ \\
\hline \multirow{18}{*}{$\begin{array}{l}\text { Course of } \\
\text { Studying }\end{array}$} & \multirow[t]{5}{*}{ B.Pharm } & $1^{\text {st }}$ Year & 79 & $15.73 \%$ \\
\hline & & $2^{\text {nd }}$ Year & 72 & $14.34 \%$ \\
\hline & & $3^{\text {rd }}$ Year & 82 & $16.73 \%$ \\
\hline & & $4^{\text {th }}$ Year & 43 & $8.36 \%$ \\
\hline & & Total & 276 & $54.98 \%$ \\
\hline & \multirow[t]{3}{*}{ D.Pharm } & $1^{\text {st }}$ Year & 56 & $11.15 \%$ \\
\hline & & $2^{\text {nd }}$ Year & 38 & $07.56 \%$ \\
\hline & & Total & 94 & $18 / 72 \%$ \\
\hline & \multirow[t]{3}{*}{ M.pharm } & $1^{\text {st }}$ Year & 17 & $03.38 \%$ \\
\hline & & $2^{\text {nd }}$ Year & 13 & $02.58 \%$ \\
\hline & & Total & 30 & $05.97 \%$ \\
\hline & \multirow[t]{7}{*}{ PharmD } & $1^{\text {st }}$ Year & 24 & $04.98 \%$ \\
\hline & & $2^{\text {nd }}$ Year & 23 & $04.78 \%$ \\
\hline & & $3^{\text {rd }}$ Year & 22 & $04.38 \%$ \\
\hline & & $4^{\text {th }}$ Year & 02 & $00.39 \%$ \\
\hline & & $5^{\text {th }}$ Year & 12 & $02.98 \%$ \\
\hline & & $6^{\text {th }}$ Year & 24 & $04.98 \%$ \\
\hline & & Total & 102 & $20.31 \%$ \\
\hline \multirow[t]{2}{*}{ Nationality } & \multicolumn{2}{|c|}{ Indian } & 488 & $97.22 \%$ \\
\hline & \multicolumn{2}{|c|}{ Others } & 14 & $02.78 \%$ \\
\hline \multirow{3}{*}{$\begin{array}{l}\text { Place of } \\
\text { origin }\end{array}$} & \multicolumn{2}{|c|}{ Urban } & 322 & $64.14 \%$ \\
\hline & \multicolumn{2}{|c|}{ Rural } & 180 & $35.86 \%$ \\
\hline & \multicolumn{2}{|c|}{ Total } & 502 & $100 \%$ \\
\hline
\end{tabular}

Table 1: Demographic details of the study population.

in individual. In addition $13.34 \%$ people's statement showed that they were not at all known that vaccination could provide active immunity. And 31.47\% were lacking adequate knowledge about; passive immunization is the transfer of antibody produced by the human or animal to another.

The routine immunization sessions from the birth are necessary, however $17.92 \%$ were not known about this procedure. All vaccinations have to be completed as per the schedule of the program although $11.15 \%$ in any case didn't know about the consequences that could happen in the coming days. Immunization is important in the day to day life and about $70 \%$ of the immunization are received to children younger than 2 still and all this information about the vaccination was incognizant by a group of $23.90 \%$ population. So as to maintain the strength of the vaccine it should be stored at 2-8 degree Celsius yet $31.07 \%$ responded for don't know. In addition the knowledge about the loss of potency of freeze vaccination if not froze properly were $51.59 \%$. About a percentage of $37.45 \%$ didn't know about the temperature that should be maintained by the freeze-dried vaccine and diluents.

The possibilities of AEFI if the reconstituted vaccines are not discarded were not known by $32.27 \%$. Sterilizing hands as a procedure in administering vaccination were not aware for $9.76 \%$. There could be adverse reactions due to vaccination though $69.92 \%$ supported the fact $9.56 \%$ were not ready to accept the mild adverse reactions that could make by vaccination. And $28.08 \%$ were not known about the adverse events that could be due to the components in the vaccine like adjutants, stabilizers, antibiotics and preservatives. $19.32 \%$ were perplexed whether to report an adverse event or not?, $8.56 \%$ were not in favor with immunization programs. $6.17 \%$ were not ready to recommend vaccination to others and 6.97 did not know if they need to recommend immunization to others. Complete answers to the KP questionnaire on safe and quality use of vaccines are presented in table 2 .

From the entire study population, $84.86 \%(n=426)$ students possessed adequate knowledge on safe and quality use of vaccines. Knowledge level was comparatively high among female gender $(12.39 \pm 3.50)$, Indian national $(12.33 \pm 3.90)$ and students from urban residential background $(12.79 \pm 3.61)$. More than $80 \%$ of study population belongs to different categories possessed adequate knowledge level except other than Indian nationals (74.42\%), population from rural residential area (77.22\%) and D.Pharm students (78.72\%). Among students of different courses, PharmD students (93.13\%) possessed adequate knowledge level with a mean knowledge score of $13.95 \pm 3.17$.

There was a statistically significant difference in the knowledge score of study population belong to categories such as Indian and other nationals ( $p$ 0.03), urban and rural place of origin ( $p$ 0.001) and students of different courses ( $\mathrm{p}$ 0.001). More information on the knowledge scores of study population with statistical analysis is presented in table 3 . 


\begin{tabular}{|c|c|c|c|c|}
\hline $\begin{array}{l}\text { Sl. } \\
\text { No }\end{array}$ & Questions & $\begin{array}{c}\text { Yes } \\
\text { n (\%) }\end{array}$ & $\begin{array}{c}\text { No } \\
\text { n (\%) }\end{array}$ & $\begin{array}{l}\text { Do not know } \\
\text { n (\%) }\end{array}$ \\
\hline \multicolumn{5}{|c|}{ Knowledge Question } \\
\hline 1. & Vaccination prevents diseases & $469(93.42 \%)$ & $17(3.38 \%)$ & $16(3.18 \%)$ \\
\hline 2. & Vaccination is the most cost effective public health intervention & $386(76.89 \%)$ & $72(14.34 \%)$ & $44(8.76 \%)$ \\
\hline 3. & Vaccination is for all age & $325(64.74 \%)$ & $129(25.69 \%)$ & $48(9.56 \%)$ \\
\hline 4. & Can vaccination enhance immunity of an individual? & $415(82.66 \%)$ & $38(7.56 \%)$ & $49(9.76 \%)$ \\
\hline 5. & Vaccination produces active immunity & $380(75.69 \%)$ & $67(13.34 \%)$ & $55(10.95 \%)$ \\
\hline 6. & $\begin{array}{l}\text { Passive immunization is the transfer of antibody produced by a human } \\
\text { or animal to another. }\end{array}$ & $279(55.57 \%)$ & $65(12.94 \%)$ & $158(31.47 \%)$ \\
\hline 7. & $\begin{array}{l}\text { Initiation of potential routine immunizations schedule should be on the } \\
\text { first day of child's birth }\end{array}$ & $321(63.94 \%)$ & $90(17.92 \%)$ & $91(18.12 \%)$ \\
\hline 8. & Is completion of vaccination as per schedule is important? & $429(85.45 \%)$ & $17(3.38 \%)$ & $56(11.15 \%)$ \\
\hline 9. & $\begin{array}{c}\text { Children younger than } 2 \text { years received more than } 70 \% \text { of immunization } \\
\text { doses? }\end{array}$ & $298(59.36 \%)$ & $84(16.73 \%)$ & $120(23.90 \%)$ \\
\hline 10. & Is it true that most of vaccines are stored at 2-8 degree Celsius? & $300(59.76 \%)$ & $46(9.16 \%)$ & $156(31.07 \%)$ \\
\hline 11. & $\begin{array}{l}\text { Does exposure to heat during transportation shortens half life of } \\
\text { vaccines? }\end{array}$ & $306(60.95 \%)$ & $44(8.76 \%)$ & $152(30.27 \%)$ \\
\hline 12. & $\begin{array}{l}\text { Freezing the vaccines that should not be frozen causes irreversible loss } \\
\text { of potency }\end{array}$ & $259(51.59 \%)$ & $68(13.54 \%)$ & $175(34.86 \%)$ \\
\hline 13. & $\begin{array}{l}\text { When reconstituting, both the freeze-dried vaccine and the diluents } \\
\text { must be at the same temperature (between 2C-8C). }\end{array}$ & $254(50.59 \%)$ & $60(11.95 \%)$ & $188(37.45 \%)$ \\
\hline 14. & $\begin{array}{l}\text { All reconstituted vaccines should be discarded at the end of the session, } \\
\text { or after six hours, whichever is the earlier. }\end{array}$ & $306(60.95 \%)$ & $34(6.77 \%)$ & $162(32.27 \%)$ \\
\hline 15. & Sterilizing hands before administering the vaccine is important. & $429(85.45 \%)$ & $24(4.78 \%)$ & $49(9.76 \%)$ \\
\hline 16. & $\begin{array}{l}\text { The risk of a few adverse reactions to vaccines is acceptable if the } \\
\text { majority of the population is protected against infectious disease. }\end{array}$ & $351(69.92 \%)$ & $48(9.56 \%)$ & $103(20.51 \%)$ \\
\hline 17. & $\begin{array}{c}\text { Can components of vaccines like stabilizers, adjutants, antibiotics, and } \\
\text { preservatives also cause adverse events? }\end{array}$ & $294(58.56 \%)$ & $67(13.34 \%)$ & $141(28.08 \%)$ \\
\hline 18. & $\begin{array}{l}\text { Do we need to report the adverse events following immunization to } \\
\text { regulatory agency? }\end{array}$ & $370(73.70 \%)$ & $35(6.97 \%)$ & $97(19.32 \%)$ \\
\hline \multicolumn{5}{|c|}{ Attitude questions } \\
\hline 19. & Are you in favor of immunization programs & $419(83.46 \%)$ & $43(8.56 \%)$ & $40(7.96 \%)$ \\
\hline 20. & Will you recommend vaccination to others? & $436(86.85 \%)$ & $31(6.17 \%)$ & $35(6.97 \%)$ \\
\hline
\end{tabular}

Table 2: Answers to the KP questionnaire on safe and quality use of vaccines. 


\begin{tabular}{|c|c|c|c|c|c|}
\hline \multicolumn{2}{|c|}{ Particulars } & \multirow{2}{*}{$\begin{array}{c}\begin{array}{c}\text { Percentage of students } \\
\text { with adequate } \\
\text { knowledge }\end{array} \\
186(81.22 \%)\end{array}$} & \multirow{2}{*}{$\begin{array}{c}\text { Percentage of students } \\
\text { with inadequate } \\
\text { knowledge }\end{array}$} & \multirow{2}{*}{$\begin{array}{c}\text { Mean } \\
\text { knowledge } \\
\text { score } \pm \text { SD } \\
12.16 \pm 4.3\end{array}$} & \multirow{2}{*}{$\begin{array}{c}\text { P Value } \\
0.37\end{array}$} \\
\hline Gender ${ }^{\#}$ & Male & & & & \\
\hline & Female & $238(87.17 \%)$ & $35(12.82 \%)$ & $12.39 \pm 3.50$ & \\
\hline \multirow[t]{2}{*}{ Nationality ${ }^{\#}$} & Indian & $414(84.83 \%)$ & $74(15.16 \%)$ & $12.33 \pm 3.90$ & \multirow[t]{2}{*}{0.03} \\
\hline & Others & $10(74.42 \%)$ & $04(28.57 \%)$ & $10.85 \pm 3.87$ & \\
\hline \multirow{2}{*}{$\begin{array}{l}\text { Place of } \\
\text { origin }^{\#}\end{array}$} & Urban & $285(88.50 \%)$ & $37(11.49 \%)$ & $12.79 \pm 3.61$ & \multirow[t]{2}{*}{0.001} \\
\hline & Rural & $139(77.22 \%)$ & $41(22.77 \%)$ & $11.38 \pm 4.24$ & \\
\hline \multirow[t]{4}{*}{ Courses* } & B. Pharm & $229(82.97 \%)$ & $47(17.02 \%)$ & $12.16 \pm 4.06$ & \multirow[t]{4}{*}{0.001} \\
\hline & M.Pharm & $26(86.66 \%)$ & $04(13.33 \%)$ & $12.82 \pm 3.78$ & \\
\hline & D.Pharm & $74(78.72 \%)$ & $20(21.27 \%)$ & $10.73 \pm 3.49$ & \\
\hline & PharmD & $95(93.13 \%)$ & $07(06.86 \%)$ & $10.65 \pm 3.49$ & \\
\hline
\end{tabular}

Tests Performed: \# Unpaired t test * ANOVA.

Table 3: Knowledge Scores of study population.

There was no statistically significant difference in the knowledge score of students of different years of various courses. The statistical analysis of the knowledge score of students of different years of each course is presented in table 4.

\begin{tabular}{|c|c|c|c|c|c|}
\hline \multicolumn{2}{|c|}{ Particulars } & \multirow{2}{*}{$\begin{array}{c}\begin{array}{c}\text { Percentage of students } \\
\text { with adequate } \\
\text { knowledge }\end{array} \\
64(81.01 \%)\end{array}$} & \multirow{2}{*}{$\begin{array}{c}\begin{array}{c}\text { Percentage of students } \\
\text { with inadequate } \\
\text { knowledge }\end{array} \\
15(18.9 \%) \\
\end{array}$} & \multirow{2}{*}{$\begin{array}{c}\begin{array}{c}\text { Mean knowledge } \\
\text { score } \pm \text { SD }\end{array} \\
11.62 \pm 3.57\end{array}$} & \multirow{2}{*}{ P Value } \\
\hline \multirow{4}{*}{ B.Pharm* } & $1^{\text {st }}$ year & & & & \\
\hline & $2^{\text {nd }}$ year & $57(79.16 \%)$ & $15(20.83 \%)$ & $11.93 \pm 4.66$ & \multirow{3}{*}{0.314} \\
\hline & $3^{\text {rd }}$ year & $73(89.02 \%)$ & $09(10.97 \%)$ & $12.76 \pm 4.12$ & \\
\hline & $4^{\text {th }}$ year & $36(83.72 \%)$ & $07(16.27 \%)$ & $12.38 \pm 3.52$ & \\
\hline \multirow[t]{2}{*}{ D.Pharm" } & $1^{\text {st }}$ year & $41(73.21 \%)$ & $15(26.78 \%)$ & $10.58 \pm 3.73$ & \multirow{2}{*}{0.630} \\
\hline & $2^{\text {nd }}$ year & $33(86.84 \%)$ & $5(13.15 \%)$ & $10.94 \pm 3.08$ & \\
\hline \multirow[t]{2}{*}{ M.Pharm ${ }^{\#}$} & $1^{\text {st }}$ year & $17(94.44 \%)$ & $01(05.55 \%)$ & $13.88 \pm 2.92$ & \multirow{2}{*}{0.74} \\
\hline & $2^{\text {nd }}$ year & $09(75.00 \%)$ & $03(25.00 \%)$ & $11.18 \pm 4.32$ & \\
\hline \multirow{6}{*}{ PharmD* } & $1^{\text {st }}$ year & $24(96.00 \%)$ & $01(04.00 \%)$ & $14.84 \pm 2.89$ & \multirow{6}{*}{0.406} \\
\hline & $2^{\text {nd }}$ year & $23(95.83 \%)$ & $01(04.16 \%)$ & $13.37 \pm 2.7$ & \\
\hline & $3^{\text {rd }}$ year & $22(91.66 \%)$ & $02(08.33 \%)$ & $13.6 \pm 3.39$ & \\
\hline & $4^{\text {th }}$ year & $02(100.00 \%)$ & $00(00.00 \%)$ & $15.5 \pm 2.5$ & \\
\hline & $5^{\text {th }}$ year & $12(80.00 \%)$ & $03(20.00 \%)$ & $13.06 \pm 4.2$ & \\
\hline & $6^{\text {th }}$ year & $12(100.00 \%)$ & $00(00.00 \%)$ & $14.6 \pm 1.79$ & \\
\hline
\end{tabular}

Tests Performed: \# Unpaired t test* ANOVA.

Table 4: Knowledge scores of students of different years of each courses. 
The lowest mean attitude score was observed among the category of study population belonged to nationalities other than India $(1.42 \pm 0.54)$. Statistically significant difference in the mean score was observed among the study population of Indian and other nationals and belong to students of different courses with the highest mean score observed among PharmD students $(1.88 \pm 0.52)$. More details on the attitude scores are presented in table 5 .

\begin{tabular}{|c|c|c|c|}
\hline \multicolumn{2}{|c|}{ Particulars } & $\begin{array}{l}\text { Mean Attitude } \\
\text { score } \pm \text { SD }\end{array}$ & P Value \\
\hline \multirow{2}{*}{ Gender $\#$} & Male & $1.66 \pm 0.52$ & \multirow{2}{*}{0.15} \\
\hline & Female & $1.73 \pm 0.53$ & \\
\hline \multirow{2}{*}{ Nationality" } & Indian & $1.70 \pm 0.53$ & \multirow{2}{*}{0.001} \\
\hline & Others & $1.42 \pm 0.54$ & \\
\hline \multirow{2}{*}{ Place of origin" } & Urban & $1.71 \pm 0.52$ & \multirow{2}{*}{0.54} \\
\hline & Rural & $1.67 \pm 0.53$ & \\
\hline \multirow{4}{*}{ Courses* } & B.Pharm & $1.6 \pm 0.57$ & \multirow{4}{*}{0.001} \\
\hline & D.Pharm & $1.61 \pm 0.61$ & \\
\hline & M.Pharm & $1.68 \pm 0.55$ & \\
\hline & PharmD & $1.88 \pm 0.52$ & \\
\hline
\end{tabular}

Tests Performed:\# Unpaired t test* ANOVA.

Table 5: Attitude Scores of Study Population.

There was no statistically significant difference in the attitude score of students of different years of various courses except Pharm.D students with a highest mean score observed among $\mathrm{V}$ PharmD students $(1.93 \pm 0.56)$. The statistical analysis of the mean score of students of different years of each course is presented in table 6.

\section{Discussion}

The cross sectional study conducted to evaluate Pharmacy students knowledge and attitude of on safe and Quality Use of Vaccines from a Pharmacy College. Similar study conducted at International Islamic University (IIUM) Malaysia, enrolled students only $3^{\text {rd }}$ Year Pharmacy students and hence enrolled only 89 students where as the current study enrolled a total of 502 students studying different Pharmacy Courses such as D.Pharm, B.Pharm, PharmD and M.Pharm. There was no much difference in the geneder distribution in ours study where as the previously mentioned study had high female predominance. Majority of the study population in the

\begin{tabular}{|c|c|c|c|}
\hline \multicolumn{2}{|c|}{ Particulars } & \multirow{2}{*}{$\begin{array}{c}\begin{array}{c}\text { Mean Attitude } \\
\text { score } \pm \text { SD }\end{array} \\
1.75 \pm 0.59\end{array}$} & \multirow{2}{*}{$\begin{array}{c}\text { P Value } \\
0.291\end{array}$} \\
\hline B.Pharm* & $1^{\text {st }}$ year & & \\
\hline & $2^{\text {nd }}$ year & $1.65 \pm 0.64$ & \\
\hline & $3^{\text {rd }}$ year & $1.68 \pm 0.58$ & \\
\hline & $4^{\text {th }}$ year & $1.59 \pm 0.54$ & \\
\hline \multirow[t]{2}{*}{ D.Pharm ${ }^{\#}$} & $1^{\text {st }}$ year & $1.58 \pm 0.60$ & \multirow[t]{2}{*}{0.62} \\
\hline & $2^{\text {nd }}$ year & $1.00 \pm 0.56$ & \\
\hline \multirow[t]{2}{*}{ M.Pharm ${ }^{\#}$} & $1^{\text {st }}$ year & $1.72 \pm 0.58$ & \multirow[t]{2}{*}{0.192} \\
\hline & $2^{\text {nd }}$ year & $1.41 \pm 0.57$ & \\
\hline \multirow[t]{6}{*}{ PharmD* } & $1^{\text {st }}$ year & $1.96 \pm 0.32$ & \multirow[t]{6}{*}{0.001} \\
\hline & $2^{\text {nd }}$ year & $1.79 \pm 0.50$ & \\
\hline & $3^{\text {rd }}$ year & $1.87 \pm 0.56$ & \\
\hline & $4^{\text {th }}$ year & $2.00 \pm 0.57$ & \\
\hline & $5^{\text {th }}$ year & $1.93 \pm 0.56$ & \\
\hline & $6^{\text {th }}$ year & $1.83 \pm 0.56$ & \\
\hline
\end{tabular}

Tests Performed: \# Unpaired t test* ANOVA.

Table 6: Attitude scores of students of different years of each course.

IIUM study participants (66.3\%) lived in urban area and the same is observed in our study (64.14\%) as well [6].

In the current study, $84.86 \%$ students possessed adequate knowledge on safe and quality use of vaccines and the mean \pm standard deviation of knowledge and attitude scores was 12.156 \pm 3.792 . Similar study observed a knowledge and attitude score of $11.7614 \pm 3.3$, which was the score of $3^{\text {rd }}$ year Pharmacy students. The current study scored the KP score of $12.76 \pm 4.12$ for $3^{\text {rd }}$ year B.Pharm students and $13.6 \pm 3.39$ for $3^{\text {rd }}$ year Pharm.D students. Both the values were more when compared to the previous study concuted in Malaysia [6].

The knowledge score of students of Indian nationals are higher when compared to the other nationals. The representation of national other than Indian were less $(n=14)$ and the other reason for less score might be due to the change in the immunization activities in their country by the health department. In India, the immunization coverage [10] is high (86.7\%) when compared to African countries (72\%) [11], from where our students are from. Hence, the KP would be less among them. It is also noticed that KP score 
is high among population from Urban residential area when compared to study population from rural area. Previosu studies also observed that immunization coverage is high among people from Urban when compared to Rural area in India [12].

KP scores of the study population showed an increasing pattern as the year of study progress from one to the other. When comparing the KP scores of students belong to different courses, it is observed that PharmD students scored better score than the other students. This might be because of the Hepatitis B vaccination, received by them in this academic year itself and they are more focused towards clinical aspect of pharmacy section. Though the Pharmacy curriculum doesn't teach on the safe and quality use of vaccine, the study observed higher KP scores among students visiting the hospital to fulfill the curricular requirement. Among them, highest KP score was observed among the Pharm.D $6^{\text {th }}$ years as they are posted at the hospital for their internship and get postings even at Immunization centers. The orientation given before they start their internship would also help them to gain more knowledge on safe and quality use of vaccines. Results of the study suggest that B.Pharm and D.Pharm students need to be encouraged for studying more about immunization as they had scored less compared to PharmD and M.Pharm.

There was a statistically significant difference in the knowledge score of study population belong to categories such as Indian and other nationals ( $p$ 0.03), urban and rural place of origin ( $p$ 0.001) and students of different courses ( $p$ 0.001). but the results of the study conducted by IIUM, showed significant insignificant ( $\mathrm{p}>$ 0.05 ) relationships between gender, age of respondent, location (rural or urban), mother's education, family income and knowledge and attitude towards vaccination [6]. Both the study showed similar statistical significance relationship only in one category, the rural and urban residential area. The difference in this result may be due to the fact that the study population and the categories of assessment were different. There was no statistically significant difference in the knowledge score of students of different years of various courses. There was no statistically significant difference in the attitude score of students of different years of various courses except Pharm. D students with a highest mean score observed among V PharmD students $(1.93 \pm 0.56)$.

Previous studies found socioeconomic factors such as education of parents and the social media are influencing the immuni- zation related KP among students [6]. Environmental factors such as family educations as well as media promotions are also crucial in hiking the students' knowledge level. There are studies which proved the pharmacy students can help the community to prevent the vaccine preventable diseases in the community by taking part in the immunization related activities and the same is practiced in countries such as Canada and Australia [13]. Almost all the studies states that a formal education should be enhanced by the healthcare team especially pharmacist about the vaccination and the possible AEFIs. Hence, a formal education need to be provide to all students on safe and quality use of vaccines as they are the prospective health care professionals.

\section{Conclusion}

Result of the study found that the knowledge and attitude of pharmacy students on safe and quality use of vaccines are improving as the year of studies pass by. A statistically significant difference in the knowledge score was observed among students belongs to categories such as Indian nationals, urban place of origin and students of different courses. However, no significant difference was observed in the knowledge scores and attitude score of students studying different years except Pharm.D students. Study understand the need of educating the students on safe and quality use of vaccines, preferably a topic can be added in the curriculum so that more attention will be given to this important topic.

\section{Conflict of Interest}

None.

\section{Source of Funding}

None.

\section{Contributions of Authors}

All authors were involved in protocol development, conduct of study, data entry, analysis and manuscript preparation and the corresponding author reviewed and finalized the manuscript.

\section{Bibliography}

1. “Global manual on surveillance of adverse events following immunization". World health organization (2014).

2. Plotkin SL and Plotkin SA. "A short history of vaccination". In: Plotkin S, Orenstein W, Offit PA. Vaccines, 5th edition, Philadelphia: Saunders (2008). 
3. Immunization fact sheet (2018).

4. World Health Organization (WHO), United Nations Children's Fund (UNICEF), World Bank. State of the world's vaccines and immunization, 3rd ed, Geneva (2009).

5. Salmon DA., et al. "Factors Associated With Refusal of Childhood Vaccines Among Parents of School-aged Children: A CaseControl Study". Archives of Pediatrics and Adolescent Medicine 159.5 (2005): 470-476.

6. Allela OQB. "Knowledge and Attitude of Immunization among Iium Pharmacy Students". Journal of Basic and Clinical Pharmacy 8 (2017): S65-S69.

7. Cvjetkovic SJ., et al. "Knowledge and attitudes toward vaccination: A survey of Serbian students". Journal of Infection and Public Health 10.5 (2017): 649-656.

8. Rothholz MC. "The role of community pharmacies/pharmacists in vaccine delivery in the United States". Presentation to ACIP (2013).

9. Sebastian J., et al. "Is there a Role for Pharmacist in Safety Monitoring of Vaccines?". Indian Journal of Pharmaceutical Education and Research 52.2 (2018): 202-206.

10. India's Vaccination Mission Narrows Focus To Meet March 2020 Target (2020).

11. Experts caution against stagnation of immunization coverage in Africa (2019).

12. Singh PK. "Trends in Child Immunization across Geographical Regions in India: Focus on Urban-Rural and Gender Differentials". PLoS ONE 8.9 (2013): e73102.

13. Church, D., et al. "A literature review of the impact of pharmacy students in immunization initiatives". Canadian Pharmacists Journal : CPJ = Revue des pharmaciens du Canada $:$ RPC 149.3 (2016): 153-165.

\section{Assets from publication with us}

- Prompt Acknowledgement after receiving the article

- Thorough Double blinded peer review

- Rapid Publication

- Issue of Publication Certificate

- High visibility of your Published work

Website: www.actascientific.com/

Submit Article: www.actascientific.com/submission.php

Email us: editor@actascientific.com

Contact us: +919182824667 